\title{
Transpondo muros: Escritas da violência na República Democrática Alemã
}

\author{
Elcio Loureiro Cornelsen ${ }^{1}$
}

\begin{abstract}
Considering the works "Zeit-Zeugen". Inhaftiert in Berlin-Hohenschönhausen (1996), edited by Gabriele Camphausen, Folterzelle 36 Berlin-Pankow. Erlebnisbericht einer Stasihaft (1993) by Timo Zilli, Ein guter Kampf. Fakten, Daten, Erinnerungen 1945-1954 (1998) by politician Ewald Ernst, Die Stasi war mein Eckermann: oder mein Leben mit der Wanze (1991) by writer Erich Loest, and Geboren am 13. August. Der Sozialismus und ich (2004) by journalist Jens Bisky, the aim of this article is to sketch a brief study on the diverse forms and phases of the violence as an instrument of power, practiced by the State of the SED in the German Democratic Republic in the 40 years of its existence, as well as discuss some theoretical aspects, focusing especially on the concept of "literature as testimony". The five analyzed reports of auto-biographical nature adopt a crucially critical tone concerning the encroachments in a totalitarian State. "Overcoming Walls" in the 20 years after the Fall of the Berlin Wall, from this point of view, implies a denouncement attitude against forgetfulness concerning a traumatic past.
\end{abstract}

Keywords: Literature of Testimony; German Literature; German Democratic Republic; Violence; Totalitarianism.

Resumo: O objetivo do presente artigo é esboçar, a partir da interpretação das obras "ZeitZeugen”. Inhaftiert in Berlin-Hohenschönhausen (1996), organizada por Gabriele Camphausen, Folterzelle 36 Berlin-Pankow. Erlebnisbericht einer Stasihaft (1993), de Timo Zilli, Ein guter Kampf. Fakten, Daten, Erinnerungen 1945-1954 (1998) do político Ewald Ernst, Die Stasi war mein Eckermann: oder mein Leben mit der Wanze (1991), do escritor Erich Loest, e Geboren am 13. August. Der Sozialismus und ich (2004), do jornalista Jens Bisky, um breve estudo sobre as diversas formas e fases da violência enquanto instrumento de poder, praticada pelo Estado do SED na República Democrática Alemã nos 40 anos de sua existência, e discutir especialmente alguns aspectos teóricos sobre o conceito de "literatura de testemunho". Os cinco relatos analisados, de caráter memorialista e autobiográfico, se pautam por um tom decididamente crítico frente aos desmandos num Estado totalitário. “Transpor muros” nos 20 anos após a Queda do Muro de Berlim, desse ponto de vista, implica um olhar memorialista de denúncia contra o esquecimento frente a um passado traumático.

Palavras-chave: Literatura de Testemunho; Literatura Alemã; República Democrática Alemã; Violência; Totalitarismo.

Zusammenfassung: Ziel dieses Beitrags ist, anhand der Interpretation der Werke "ZeitZeugen”. Inhaftiert in Berlin-Hohenschönhausen (1996), herausgegeben von Gabriele Camphausen, Folterzelle 36 Berlin-Pankow. Erlebnisbericht einer Stasihaft (1993) von Timo Zilli, Ein guter Kampf. Fakten, Daten, Erinnerungen 1945-1954 (1998) des Politikers Ewald Ernst, Die Stasi war mein Eckermann: oder mein Leben mit der Wanze (1991) des Schriftstellers Erich Loest, und Geboren am 13. August. Der Sozialismus und ich (2004) des Journalisten Jens Bisky, eine kleine Studie über die verschiedenen Formen und Phasen der

\footnotetext{
1 Professor adjunto da Faculdade de Letras da Universidade Federal de Minas Gerais; endereço eletrônico: cornelsen@letras.ufmg.br
} 
Gewalt zu präsentieren, die vom SED-Staat in der Deutschen Demokratischen Republik in den 40 Jahren ihrer Existenz als Instrument der Macht angewandt wurde, und besonders einige theoretische Aspekte über den Begriff von „Zeugnisliteratur“ zu erörtern. Die fünf analysierten Berichte memorialistischer und autobiographischer Art beruhen auf einem entscheidend kritischen Ton bezüglich der Übergriffe in einem totalitären Staat. „Mauern überwinden“ in den 20 Jahren nach dem Fall der Berliner Mauer, aus diesem Blickwinkel betrachtet, impliziert eine memorialistische Sicht von Denunzierung gegen das Vergessen gegenüber einer traumatischen Vergangenheit.

Stichwörter: Zeugnisliteratur; Deutsche Literatur; Deutsche Demokratische Republik; Gewalt; Totalitarismus.

\section{Introdução: transpondo muros para além de uma "Literatura da Virada”}

O processo histórico que culminou com a Queda do Muro de Berlim em 09 de novembro de 1989 e com a conseqüente Reunificação alemã, oficialmente celebrada em 03 de outubro de 1990 - período da chamada Wende ("Virada”, “Transição”) -, como não poderia deixar de ser, tem tido reflexo sobre a produção literária na Alemanha. Neste ano de 2009, em que se comemoram 20 anos da Queda do Muro, busca-se, justamente, um balanço da "Literatura da Virada”. Como aponta Jörg MAGENAU (2009: 56), “o 'annus mirabilis’ é um tema, mas com muitas facetas”. Na longa lista de obras que contemplam o tema da "Virada" figuram títulos recentes como Die Nacht, in der die Mauer fiel (2009; “A noite em que o Muro caiu”), uma antologia de recordações de escritores a respeito de suas vivências naquele dia histórico, Amateure (2009; “Amadores”), de Angelika Klüssendorf, uma antologia de contos em que a "Virada” é abordada ficcionalmente a partir das histórias trágicas de casais, ou ainda os romances Helden wie wir (1995; “Heróis como nós”) e Wie es leuchtet (2004; “Como brilha”), de Thomas Brussig, Simple storys (1998) e Neue Leben (2005; “Novas Vidas”), de Ingo Schulze, e Der Turm (2008; “A torre”), de Uwe Tellkamp.

Sem dúvida, a crítica alemã, em geral, considera Thomas Brussig e Ingo Schulze como os escritores que melhor têm trabalhado ficcionalmente a temática da "Virada" nos últimos 20 anos. Inclusive, suas obras representam uma das vertentes dentro do cenário literário alemão, mais precisamente a "literatura ostálgica”. Trata-se de uma vertente expressiva que se formou, sobretudo, em torno da maneira como jovens escritores, que nasceram e cresceram na antiga Alemanha Oriental, refletem sobre seu próprio passado. Alguns críticos de literatura falam pejorativamente de certa "ostalgia” 
(Ostalgie, termo composto de Ost - Oriente - e Nostalgie, nostalgia), uma postura nostálgica ou apaziguadora em relação à vida na antiga Alemanha Oriental (CORNELSEN 2008b: 138). Nesse processo de elaboração literária, tudo depende das vivências de escritores no antigo Estado socialista. Aqueles que conseguem “fazer as pazes” com o passado vivenciado na RDA ou que criticam os rumos da sociedade alemã durante e após a "Virada" que reunificou o país valem-se do humor ou da ironia em suas obras, que acabam, de certo modo, enfraquecendo e, com isso, rasurando o caráter totalitário do regime do SED - Sozialistische Einheitspartei Deutschlands ("Partido Socialista Unitário da Alemanha”). Tal postura fica patente, por exemplo, nas palavras do escritor Thomas Brussig que, ao tecer comentários sobre o romance Am kürzeren Ende der Sonnenallee (1999; "No extremo mais curto da Alameda do Sol”) ${ }^{2}$ em entrevista concedida a Silke LAMBECK (1999), aponta o aspecto biográfico como fundamental para a elaboração de um quadro ficcional do passado na RDA, cujo norteador seria um sentimento nostálgico em relação à própria vivência em Berlim Oriental:

\begin{abstract}
Minha infância se passou na RDA. Por isso, não devo me recordar de minha infância com prazer? Também escrevi "No extremo mais curto da Alameda do Sol" porque levei a sério a nostalgia. Ele se tornou um livro muito afetivo. Eu sempre dizia: ele deve se tornar um livro que, ao lê-lo, até mesmo alemães ocidentais sintam inveja de não terem tido permissão para viver na RDA. Já nessa pretensão há algo enviesado. Um historiador não deveria se ocupar desse livro. ${ }^{3}$
\end{abstract}

Todavia, desde o início dos anos 90, nota-se também outra tendência crescente no cenário literário alemão que, ao contrário da "ostalgia”, ressalta os traços violentos e repressivos, constitutivos do regime totalitário do SED. Trata-se da "literatura antiostálgica”, representada por escritores que, em geral, fizeram críticas ao regime e foram perseguidos, presos, ou até mesmo tiveram de deixar a República Democrática Alemã durante o período de sua existência, e que optam por construir um quadro sombrio da sociedade e do Estado. Embora figurem alguns romances entre as obras que representam a "literatura anti-ostálgica”, como Froschkonzert (1990; “Concerto do

\footnotetext{
${ }^{2}$ Título da tradução brasileira: O charuto apagado de Churchill, tradução. de Marcelo Backes, Porto Alegre, L\&PM, 2005.

${ }^{3}$ Meine Kindheit hat in der DDR stattgefunden. Soll ich mich deshalb nicht gern an meine Kindheit erinnern? Auch deshalb habe ich „Am kürzeren Ende der Sonnenallee“ geschrieben, weil ich die Nostalgie mal ernst genommen habe. Es wurde ein sehr liebevolles Buch. Ich habe immer gesagt: Das soll ein Buch werden, bei dem sogar Westler neidisch werden, dass sie nicht in der DDR leben durften. An diesem Anspruch ist ja schon etwas Schiefes. Ein Historiker sollte sich dieses Buch nicht vornehmen.
} 
Sapo”) e Nikolaikirche (1995; “Igreja de São Nicolau”), de Erich Loest, Magdalena (1999), de Jürgen Fuchs, Krokodil im Nacken (2002; “Crocodilo na nuca”), de Klaus Kordon, e Tod eines Spitzels (2005; “Morte de um agente”), de Leon Preuss, o gênero predominante é o “relato de testemunho”, de caráter memorialista e autobiográfico.

Após a Queda do Muro de Berlim e a Reunificação alemã, foram publicados vários relatos de testemunho de vítimas do regime do SED, nos quais seus autores procuram, ao mesmo tempo, lidar com o passado traumático e denunciar os desmandos num Estado totalitário, cujas características eram a centralização do poder num partido único, fundamentado por uma ideologia de massa, o controle e a planificação da economia, o monopólio de armas, propaganda e informação, o controle da produção científica e cultural, bem como o emprego de aparelhos censores e repressores no combate a toda e qualquer opinião ou postura divergente. Não obstante o número significativo de publicações de relatos de testemunho ao longo dos últimos 20 anos na Alemanha, pouca atenção se tem dado a essa literatura em detrimento daquela que é apoiada pelo mercado editorial e seus instrumentos de divulgação - prêmios literários, feiras do livro, revistas especializadas etc. É esse aspecto que, justamente, nos levou, neste artigo, a optar pela análise de obras que pertencem à “literatura anti-ostálgica”.

A partir da interpretação das obras “Zeit-Zeugen”. Inhaftiert in BerlinHohenschönhausen (1996; “'Testemunhos do tempo’. Detidos em BerlimHohenschönhausen”), organizada por Gabriele Camphausen, Folterzelle 36 BerlinPankow. Erlebnisbericht einer Stasihaft (1993; “Cela de tortura 36 Berlim-Pankow. Relato de vivência numa prisão da Stasi”), de Timo Zilli, Ein guter Kampf. Fakten, Daten, Erinnerungen 1945-1954 (1998; “Uma boa luta. Fatos, datas, recordações 19451954”), do político Ewald Ernst, Die Stasi war mein Eckermann: oder mein Leben mit der Wanze (1991; “A Stasi foi meu secretário: ou minha vida com a escuta”), do escritor Erich Loest, e Geboren am 13. August. Der Sozialismus und ich (2004; “Nascido em 13 de agosto. O socialismo e eu”), do jornalista Jens Bisky, será apresentado, a seguir, um quadro contendo as diversas formas e fases da violência praticada pelo Estado na RDA, reconstruído a partir de textos memorialísticos e autobiográficos.

É importante salientar de antemão que tais textos diferenciam-se não só no modo como seus autores lidam com o passado a partir da vivência de eventos traumáticos (Weber in Camphausen; Zilli; Ernst) ou de um olhar memorialista (Bisky), como também por questões formais, onde se constata a associação entre relato e documento 
(Zilli; Ernst; Loest), ou ainda pela implicação de fatores que dizem respeito a peculiaridades da própria prática repressiva e da burocracia na República Democrática Alemã que hoje colaboram para a reconstrução do passado naquele país (Zilli; Loest).

Como fundamentação teórica, lançaremos mão de conceitos oriundos dos estudos sobre a teoria do testemunho no âmbito da Literatura (FELMAN, GAGNEBIN, Nestrovski, Seligmann-Silva, SEnKman), em que figuram noções como "literatura de trauma” (NESTROVSKI; SELIGMANN-SiLVA), “cisão entre linguagem e evento" (SELIGMANN-SiLVA, 2003: 46-47), as categorias de testemunho enquanto "testis" (testemunha; espectador), “superstes” (testemunha; sobrevivente) “e martyros” (mártir) (SELIGMANN-SiLVA, 2003: 377-378), a necessidade de uma "ética da representação histórica” (SELIGMANN-SILVA, 2003: 74), entre outras. Cabe lembrar que, guardadas as devidas proporções, embora a teoria de testemunho (testimony; Zeugnis), nas últimas décadas, tenha sido desenvolvida a partir de discussões em torno do nazismo, da Segunda Guerra Mundial e, sobretudo, da Shoah como "evento-limite, a catástrofe, por excelência, da Humanidade e que já se transformou em definiens do nosso século” (SELIGMANN-SiLVA 2000: 75), consideramos pertinente o emprego de seu arcabouço teórico também em estudos que enfocam as escritas da violência em regimes ditatoriais na segunda metade do século XX, como é o caso da RDA.

\section{A Prisão de Hohenschönhausen e os "Testemunhos do Tempo"}

As escritas da violência cometida pelo Estado contra possíveis dissidentes políticos na RDA estão intrinsecamente atreladas à própria história de seus aparelhos

repressores e, sobretudo, das instituições prisionais. Sem dúvida, a mais significativa delas para um estudo dessa natureza é o Lager- und Haftanstalt BerlinHohenschönhausen (“Campo e Casa de Detenção Berlim-Hohenschönhausen”), localizado no $\mathrm{n}^{\circ}$. 66 da Genslerstrasse, no bairro berlinense de Hohenschönhausen. Originalmente, tratava-se de uma fábrica, cuja área foi vendida em 1938 à organização nazista NSV - Nationalsozialistische Volkswohlfahrt ("Bem Público NacionalSocialista”), onde funcionava uma grande cozinha de assistência a pessoas carentes. Em 1945, o complexo de prédios que compunham a antiga fábrica foi transformado numa prisão pelas autoridades soviéticas, uma vez que ele não havia sido atingido pelos bombardeios (ERLER / KNABE 2008: 55-56). 
Durante décadas, a Prisão de Hohenschönhausen foi centro de triagem e de persecução penal política na Zona de Ocupação Soviética e, posteriormente, na RDA. Sua história pode ser dividida em três fases: a primeira delas remonta aos anos de 1945 e 1946, quando a Prisão de Hohenschönhausen foi utilizada pelo Governo de ocupação soviética como Speziallager Nr. 3 (“Campo Especial n. 3”), campo de internação de prisioneiros de guerra, com capacidade para 2.500 detentos; na segunda fase de sua história, de 1947 a 1951, a prisão foi funcionalizada como centro soviético de averiguação e prisão preventiva, ainda no período de ocupação; por fim, a terceira e mais longa fase dessa instituição prisional se estende de 1951 a 1989 como casa de detenção e averiguação administrada pelo Ministerium für Staatssicherheit (MfS “Ministério de Segurança do Estado”). Hoje a antiga prisão é um Memorial - a Stiftung Gedenkstätte Berlin-Hohenschönhausen ("Fundação Memorial BerlimHohenschönhausen"; www.stiftung-hsh.de), fundado em 1995, com visitações públicas guiadas, geralmente, por pessoas que, no passado, estiveram lá detidas, e se tornou símbolo de uma justiça motivada e dominada politicamente. Pela dificuldade de investigação e pela quantidade de documentos destruídos sobre o seu funcionamento nas três fases, até hoje permanece incerto o número total de pessoas que estiveram detidas naquela prisão entre 1945 e 1989.

Não obstante a falta de tais dados, um significado especial no âmbito da investigação histórica é atribuído aos relatos de testemunho de ex-prisioneiros da Prisão de Hohenschönhausen, que complementam as pesquisas estatísticas e documentais. Seus depoimentos e informações revelam não só aspectos concretos e detalhes do funcionamento e da organização prisional em si, mas também as vivências traumáticas que deixaram marcas no próprio ato de reconstrução do passado através da memória. Como apontam NESTROVSKI e SELIGMANN-SiLVA (2000: 7-8), “a catástrofe dificulta, ou impede a representação”, pois a “catástrofe é, por definição, um evento que provoca um trauma”. Os relatos de testemunho em geral pertencem, pois, à "literatura de trauma”, como ressalta NESTROVSKI (2000: 186), pois se trata de “representar o irrepresentável; resgatar, sem trair um evento latente na memória; redescobrir alguma força viva na língua, que nos torne capazes de testemunhar o que foi visto”. No caso específico deste estudo, os relatos de testemunho de ex-prisioneiros políticos auxiliam, portanto, na reconstrução daquilo que teria sido o cotidiano na Prisão de Hohenschönhausen e 
revelam também o modo como dado evento traumático pode se inscrever no próprio processo de articulação discursiva pela memória.

Uma primeira coleção de relatos de testemunho foi organizada e publicada em 1996 por Gabriele Camphausen com o título “Zeit-Zeugen”. Inhaftiert in BerlinHohenschönhausen (“'Testemunhos do tempo'. Detidos em BerlimHohenschönhausen”). ${ }^{4}$ Originalmente, essa coleção foi concebida como material de divulgação do Memorial, composto de apenas 60 páginas, incluindo 16 relatos de testemunho e várias fotos da prisão. Em termos de conteúdo, os relatos dão não só a dimensão das diversas fases históricas da instituição prisional, mas também dos diversos motivos que levaram as pessoas a serem detidas. Em geral, os relatos individuais revelam o sentimento de impotência, de abandono e de se estar numa situação indefesa diante da onipresença do aparelho de Estado.

A título de exemplo, selecionamos o relato de Sigrid Weber, que foi presa em abril de 1978 sob a acusação de espionagem. De 14 de abril de 1978 a abril de 1979 ela esteve detida na Casa de Detenção Berlim-Hohenschönhausen, e em 14 de fevereiro de 1979 foi condenada à prisão perpétua. Sigrid Weber cumpriu pena no Campo de Bautzen II, em Sachsen, até 14 de março de 1981, quando foi posta em liberdade ao ser trocada por outro prisioneiro que estava detido na Alemanha Ocidental. Ela era cidadã da República Federal da Alemanha e havia viajado por três dias para Magdeburgo, cidade da Alemanha Oriental, segundo ela, por ocasião de uma festa de família. No dia em que deixaria Magdeburgo, Sigrid Weber constatou que alguém mexera em seu automóvel e provocara algumas avarias, provavelmente ao tentar roubá-lo, e decidiu ir a uma delegacia local prestar queixa, pois pretendia apresentar à sua seguradora, em Hamburgo, o Boletim de Ocorrência. No caminho, foi detida por agentes da Stasi: ${ }^{5}$ "O motivo de minha detenção foi 'suspeita de espionagem'. Meus sentimentos ficaram paralisados. O que se passava em meu íntimo, eu não consigo descrever. Era um outro mundo” (WEBER 1996: 51). ${ }^{6}$ Noutra passagem de seu relato, Sigrid WEBER (1996: 52) revela o abalo emocional que sofreu no período em que esteve detida, após seções

\footnotetext{
${ }^{4}$ CAmphausen, Gabriele. “Zeit-Zeugen“. Inhaftiert in Berlin-Hohenschönhausen. Berlin, WestkreuzDruckerei, 1996. Além disso, foi publicado em 2007 o livro Gefangen in Hohenschönhausen. StasiHäftlinge berichten ("Detidos em Hohenschönhausen. Prisioneiros da Stasi relatam”), organizado por Hubertus Knabe (Berlin, List Taschenbuch, 2007), atual diretor do Memorial Berlim-Hohenschönhausen. ${ }^{5}$ Todas as traduções de citações ao longo do texto são de nossa autoria.

6 „[...] Der Anlass meiner Festnahme war “Verdacht der Spionage”. Meine Gefühle waren gelähmt. Was in mir vorging, kann ich nicht beschreiben. Es war eine andere Welt.“
} 
diárias de interrogatório, que duravam em torno de oito horas, e de ser submetida ao mais completo isolamento:

Em algum momento, meus nervos chegaram ao fim com toda aquela situação. Os sintomas se manifestaram em mim na forma de visões. As paredes de minha cela moviam-se. Elas vinham em minha direção. Isso significa que a cela foi ficando cada vez menor, a porta de ferro estalava continuamente abrindo e fechando. Fui conduzida a um neurologista, ao qual relatei minhas visões com a seguinte observação: "Estou ficando louca." O que ele respondeu: "Se a senhora estiver ficando louca, isso nós notaremos. Nós não chamamos a senhora aqui." 7

Em seu relato, Sigrid WeBER (1996: 52) afirma também que, apesar da situação traumática à qual foi constantemente submetida no período em que esteve detida, ela podia se lembrar do que ocorria: "Minhas recordações não se desvanecem de jeito nenhum. Não posso esquecer. Às vezes, penso que foi ontem”. ${ }^{8}$ Podemos deduzir que o trauma, neste caso, não se manifesta necessariamente numa memória lacunar, num apagamento mental, mas sim na constante presentificação do ato traumático. Devemos, entretanto, lembrar que, como ressalta SELIGMANN-SILVA (1998: 10),

[o] testemunho escrito ou falado, sobretudo quando se trata do testemunho de uma cena violenta, de um acidente ou de uma guerra, nunca deve ser compreendido com uma descrição "realista" do ocorrido. De resto, testemunhase - sempre, diria Walter Benjamin - uma cena traumática. A impossibilidade de uma tradução total da cena vivenciada é um dado a priori.

Além de afirmar a presentificação do ato traumático, Sigrid WEBER (1996: 52) descreve em seu relato o processo de aniquilamento e despersonificação total:

No início, a gente precisava comer sem talheres. No verão, tínhamos para vestir os agasalhos de treino mais grossos (forrados). Era um verão quente. Às vezes, os aquecedores eram mantidos em funcionamento. Era insuportável, Não havia nada gelado para beber. Às vezes, faltavam as necessidades mais ínfimas do ser humano. Eu trocara meu nome por um número, p.ex. cela $7, \mathrm{n}^{\circ} .1{ }^{9}$

\footnotetext{
7 „Ich war durch die ganze Situation irgendwann total nervlich am Ende. Das äußerte sich bei mir mit Erscheinungen. Meine Zellenwände bewegten sich. Sie kamen auf mich zu. Das heißt, die Zelle wurde noch kleiner, die Eisentür knallte ständig auf und zu. Ich wurde einem Neurologen vorgeführt, dem ich meine Wahrnehmungen mitteilte mit der Bemerkung: "Ich werde verrückt.” Darauf die Antwort: "Wenn Sie verrückt werden, das merken wir schon. Wir haben Sie nicht hierher gerufen.”

8 „Meine Erinnerungen verblassen so gut wie gar nicht. Ich kann nicht vergessen. Manchmal denke ich, es war erst gestern. [...]“

9 „Anfangs musste man sein Essen ohne Besteck einnehmen. Im Sommer gab es die dicksten Trainingsanzüge (gefüttert) zum Anziehen. Es war der heiße Sommer. Manchmal waren die Heizungen in Betrieb. Es war unerträglich. Nichts Kaltes zum Trinken. Manchmal fehlte es eben an den geringsten Bedürfnissen des Menschen. Meinen Namen hatte ich gegen eine Nummer getauscht, z.B. Zelle 7, Nr.1.“
} 
Ao recordar-se do período da prisão, Sigrid WEBER (1996: 52) revela também a eficácia da tortura psicológica à qual foi submetida, que lhe deixou tanto marcas psíquicas para a vida toda, quanto lhe debilitou fisicamente:

Até hoje, meus tristes sonhos não me deixaram. Eu apenas sei ainda que, naquela época, fui dominada por medos que eu não conhecia. Eu levava a sério tudo de que me ameaçavam. Fisicamente não fui molestada, o isolamento supriu todo o resto.

Quando fui libertada, eu pesava 34,5 kg. Altura 1,62 m. ${ }^{10}$

Portanto, Sigrid Weber testemunha a sua vivência da Prisão de Hohenschönhausen como algo traumático, seu testemunho se apresenta como o de um superstes, especificado por SeligmanN-Silva (2003: 378) como "a pessoa que atravessou uma provação, o sobrevivente”.

\section{A “Cela de tortura 36 Berlim-Pankow" e o "Relato de vivência numa prisão da Stasi”}

Outra obra que documenta a violência praticada nas prisões políticas da RDA é Folterzelle 36 Berlin-Pankow. Erlebnisbericht einer Stasihaft (1993; “Cela de tortura 36 Berlim-Pankow. Relato de vivência numa prisão da Stasi”), de Timo Zilli. Nascido em 22 de setembro de 1945 em Friuli, cidade do Norte da Itália, Timo Zilli (Ferrucio Zilli) chegou à Alemanha Ocidental em 1965, para trabalhar como Gastarbeiter ("trabalhador estrangeiro convidado”), fixando residência em Berlim Ocidental. Já havia estado em vários países da Europa e viajado para várias partes do mundo como marinheiro. Por assim dizer, tinha levado uma vida errante até então. Segundo seu relato, no dia 11 de novembro de 1970, ele voltava para casa, embriagado, após uma festa da firma em que trabalhava. Na estação Friedrichstrasse, na fronteira entre Berlim Ocidental e Oriental, onde tinha de baldear, ele acabou se envolvendo numa discussão com um guarda da Polícia Popular da RDA, foi espancado e conduzido à delegacia na Alexanderplatz, no lado oriental da cidade. De lá, Timo Zilli foi transferido para a Prisão de Berlim-

\footnotetext{
10 „Meine traurigen Träume haben mich bis heute nicht verlassen. Ich weiß nur noch ganz genau, dass ich damals von Ängsten beherrscht wurde, die ich so nie gekannt habe. Habe alles ernst genommen, was man mir androhte. Körperlich bin ich nicht gezüchtigt worden, die Isolierung hat alles ersetzt.

Bei meiner Entlassung wog ich 34,5 kg. Größe 1,62 m.”
} 
Pankow, onde lhe foi exigida a quantia de 20.000 marcos como fiança para sua liberação. Como se recusara a pagar tal quantia, permaneceu detido e foi condenado a uma pena de três anos e meio de reclusão sob a acusação de "campanha difamatória hostil ao Estado" (staatsfeindliche Hetze), de “cumplicidade na fuga da República” (Beihilfe zur Republikflucht) e "perigo para a ordem socialista da sociedade” (Gefahr für die sozialistische Gesellschaftsordnung). (ZILLI 1993: 16; 46) Algum tempo mais tarde, a pena foi reduzida para um ano, e ele foi transferido para o Presídio de Rummelsburg. Como prisioneiro $\mathrm{n}^{\circ}$. 856082, começa a pior fase do período de detenção, com torturas diárias - por horas, ele era pendurado pelas mãos, podendo tocar o solo apenas com as pontas dos pés, então a isso se seguia a seção de chutes e socos, sem falar na tortura psíquica causada pelo confinamento numa cela minúscula, mantida sempre na escuridão. Em outubro de 1972, Timo Zilli foi libertado após uma anistia por ocasião do $23^{\circ}$ aniversário da RDA. Quando retornou a Berlim Ocidental, para seu espanto, ninguém acreditou no que havia vivenciado, nem mesmo a Anistia Internacional. Anos mais tarde, após a Queda do Muro de Berlim, ele pôde ter acesso à documentação da Stasi relativa não só à sua prisão, mas também a um período anterior, onde a polícia secreta da RDA já controlava seus passos e atribuía a ele o codinome de "caminhante" (Wanderer). Provavelmente, a Stasi interessou-se por Timo Zilli devido a seu engajamento na revolução estudantil de 1968, da qual participou ativamente. Porém, este parece não ter sido o único motivo, mas também por ter sido membro do UEIP Union Emigranti Italiani Proletari (“União de Emigrantes Italianos Proletários”), organização ligada ao Partido Comunista Italiano, contrária à RDA e à política de Moscou, e por ter tido contato com uma jovem em Berlim Oriental, cujo irmão fugira para o lado ocidental, com o suposto auxílio de Timo Zilli.

Em 1992, Timo Zilli procurou ajuda no Behandlungszentrum für Folteropfer (“Centro de Tratamento de Vítimas de Tortura”), em Berlim, onde encontrou não só apoio psicológico, como também, de acordo com Pross (1993: 7), foi auxiliado a ter acesso à documentação da Stasi referente à sua prisão e motivado a publicar suas memórias do período de detenção na RDA. Em seu relato, ele afirma que “[e]squecer era para mim impossível, mesmo que o tempo tenha apagado certos vestígios. Mesmo após 20 anos eu não consigo esquecer” (ZILli 1993: 13). ${ }^{11}$ Além de prestar testemunho

\footnotetext{
11 „Das Vergessen war mir unmöglich, wenn auch die Zeit manche Spuren verwischt hat. Auch nach 20 Jahren kann ich nicht vergessen.“
}

Pandaemonium germanicum 13, 2009, 25-57. - www.fflch.usp.br/dlm/alemao/pandaemoniumgermanicum 
do que havia ocorrido consigo próprio, Timo ZILLI (1993: 13) também avalia seu relato como forma de prestar homenagem àqueles presos políticos que, em situações semelhantes, também conheceram de perto o sistema prisional da RDA:

\begin{abstract}
Naturalmente, este relato, que me esforcei em escrever de modo acríbico e fiel à verdade, não é uma representação das condições gerais nos presídios da Stasi com todas as suas excrescências e atrocidades. Naturalmente, na minha autêntica odisséia pela Prisão de Pankow e, posteriormente, pela Penitenciária em Rummelsburg, que me conduziu de cela a cela, de interrogador a educador, eu também vi muitas pessoas virem e irem. Também relatei seus destinos e caminhos de sofrimentos no intuito de, com isso, erigir um pequeno monumento àqueles que não encontraram e não encontram palavras, mas que não sofreram menos do que eu, e de dedicar-lhes uma pequena recordação.
\end{abstract}

Quero transmitir verdade com este livro, verdade, que apenas esperou todo esse tempo para ser externada.

Sem sentimentos de vingança, deve ocorrer uma discussão franca entre perpetradores e vítimas. ${ }^{12}$

Novamente, nos deparamos nessa passagem com o apelo à “verdade” por parte daquele que testemunha, como se o acesso ao "real" vivenciado não estivesse, de antemão, comprometido pelo trauma. Mas, mais uma vez, devemos ter atenção para o fato de que, conforme indica SELIGMANN-SiLVA (2003: 46-47):

O testemunho coloca-se desde o início sob o signo da sua simultânea necessidade e impossibilidade. Testemunha-se um excesso de realidade e o próprio testemunho enquanto narração testemunha uma falta: a cisão entre a linguagem e o evento, a impossibilidade de recobrir o vivido (o "real”) com o verbal. [...]

Por sua vez, ao ter tido acesso à documentação de sua prisão através da Behörde des Bundesbeauftragten für die Unterlagen des Staatssicherheitsdienstes der ehemaligen DDR (BStU - "Repartição do Encarregado Federal dos Documentos do Serviço de Segurança de Estado da antiga RDA”), Timo ZILLI (1993: 14) pôde

\footnotetext{
12 „Natürlich ist dieser Bericht, den ich mich bemüht habe, akribisch und wahrheitsgetreu zu schreiben, keine Schilderung der gesamten Verhältnisse in den Stasi-Zuchthäusern mit all ihren Auswüchsen und Abscheulichkeiten. Natürlich habe ich in meiner wahren Odyssee durch die U-Haft in Pankow und den späteren Strafvollzug in Rummelsburg, der mich von Zelle zu Zelle, von Vernehmer zu Erzieher führte, auch viele Menschen kommen und gehen sehen. Auch deren Schicksale und Leidenswege habe ich geschildert, um damit denjenigen, die keine Worte fanden und finden, die aber nicht minder gelitten haben wie ich, ein kleines Denkmal zu setzen, ihnen eine kleine Erinnerung zu widmen.

Ich will mit diesem Buch Wahrheit verbreiten, Wahrheit, die nur allzulange darauf gewartet hat, transportiert zu werden.

Ohne Rachgefühle muss eine offene Diskussion stattfinden zwischen Tätern und Opfern.“
} 
encontrar dados concretos, protocolos, depoimentos, mas não encontrou o que mais procurava: "Faltavam todas as referências dos métodos miseráveis que eles haviam empregado, o que eles fizeram comigo na 'cela de tortura 36', que me colocaram na cela escura. Faltavam todas as referências de como eles tinham atentado contra a minha dignidade humana de maneira bárbara”. ${ }^{13}$ A documentação dos arquivos da Stasi traziam detalhes burocráticos de etapas referentes a relatórios de investigação, detenção, interrogatórios e condenação, mas não dos procedimentos práticos e dos excessos cometidos.

Em seu relato, Timo Zilli presta testemunho de seu caso, desde a prisão até a libertação, da visita que fez nos anos 90 ao local onde esteve preso e do trauma vivenciado e ainda presente em sua memória, 20 anos após o ocorrido. Como dito anteriormente, ele relata também o destino comum de outros detentos, figurando, assim, não só como um sobrevivente, um superstes, mas também como testis (SELIGMANNSILVA 2003: 377), ou seja, como testemunha de atos violentos cometidos contra terceiros, como demonstra a seguinte passagem de seu relato (ZILLI 1993: 101-102):

\begin{abstract}
De minha cela eu ouvi, de repente, o grito de uma mulher. De novo, estavam tentando subjugar alguém. Para isso, todo método lhes era legítimo. A mulher, aparentemente, foi arrastada escada abaixo com violência. Ela gritou: "Soltemme.” Depois, ouviram-se gritos de dor. "Largue meus seios, seu porco perverso!”

Pôde-se ouvir um barulho, e os portões de meu andar foram abertos. Em toda a ala estava um silêncio completo. Apenas os gritos horríveis da mulher podiam ser ouvidos, e o xingamento do pessoal da Stasi: "Vamos dar uma lição a essa puta!” Pouco depois, começaram as batidas e o código-morse pelas paredes. Também chegou através do "Leo" a notícia: "Helga está sendo espancada."

Eu espreitei junto à porta. Eles a arrastavam pelo corredor, puxavam-na pelos cabelos, e ela gritava. Eu sabia para onde a levavam. Eu me encontrava na antiga ala, e se eles corriam em minha direção, isso só poderia significar uma coisa: cela $36 .^{14}$
\end{abstract}

\footnotetext{
13 „,...] Es fehlten alle Hinweise auf die miserablen Methoden, die sie angewandt hatten, was sie in der "Folterzelle 36" mit mir trieben, dass sie mich in Dunkelhaft steckten. Es fehlten jegliche Hinweise darauf, wie sie in barbarischer Manier meine Menschenwürde angetastet hatten.“

14 „Von meiner Zelle aus hörte ich plötzlich das Geschrei einer Frau. Schon wieder waren sie dabei, jemanden kleinzukriegen. Dabei war ihnen jede Methode recht. Die Frau wurde anscheinend mit Gewalt die Treppe heruntergezerrt. Sie schrie: “Lassen Sie mich los.” Dann waren wieder Schmerzensschreie zu hören. "Lassen Sie meine Brust, Sie perverses Schwein!”

Ein Poltern war zu hören, und die Tore zu meiner Etage gingen auf. Im ganzen Trakt war es mucksmäuschenstill. Nur die entsetzlichen Schreie der Frau waren zu hören und das Geschimpfe der Stasi-Leute: “Der Nutte werden wir es beibringen!” Kurz darauf gingen die Klopf- und Morsezeichen durch die Wände. Auch über "Leo” kam die Nachricht: "Helga wird geschlagen.”

Ich horchte an der Tür. Sie schleppten sie den Korridor entlang, sie zogen sie an den Haaren, und sie schrie. Ich wusste, wo es langging. Ich befand mich im alten Trakt, und wenn sie in meine Richtung liefen, konnte das nur eines bedeuten: Zelle 36.“
} 
Nessa passagem, identificamos também alguns dados sobre a forma como os prisioneiros se comunicavam, através de batidas na parede codificadas, que eles denominavam de “código-morse”, e também o "Leo”, que, na verdade, era o vaso sanitário, do qual se reduzia o nível de água e se utilizava como "telefone” entre as celas.

Por sua vez, o relato de Timo Zilli, em sua maior parte, se constitui do testemunho da violência perpetrada contra a sua pessoa, o que o coloca na situação de superstes, ou seja, do sobrevivente, daquele que relata sobre a própria vivência traumática à qual foi exposto (ZILLI 1993: 71):

\begin{abstract}
Naturalmente, eles entraram em ação imediatamente com golpes de cassetete e chutes e me jogaram no chão. Eles me seguraram firme e eu fui colocado sobre um catre de madeira que se encontrava do lado direito da cela, com a barriga voltada para baixo. Eles esticaram meus braços e pernas e me algemaram nas mãos e nos calcanhares. Uma sentinela pressionou seu joelho nas minhas costas, dois outros ergueram minhas mãos presas para trás, por sobre a cabeça até as costas, e outros dois fizeram o mesmo com as pernas. Então, o oficial prendeu com uma outra algema mãos e pernas. Eu estava feito um cavalo de balanço, apenas as extremidades das costelas tinham contato com o catre. Quando eu movia os braços, as pernas se erguiam. Pensei que, a qualquer momento, todos os ossos em meu corpo se quebrariam. A pior dor veio das costelas, onde a pele ficou vermelha e gerou escoriações. Com um açoite de aço entre os dentes fui, ainda, amordaçado. O oficial puxou-me para frente pelos cabelos e disse: "Nós temos tempo, podemos esperar." 15
\end{abstract}

Tal cena hedionda ocorreu na “cela 36”, temida por todos os detentos da Prisão de Pankow, que representa a própria materialidade da espacialização da violência em todo o livro de Timo Zilli, o que justifica seu título. Nota-se também o detalhamento na descrição da cena, em que predomina a literalidade, a qual, como nos lembra SeligmanN-Silva (2000: 91), “é, antes de tudo, marcada por um 'excesso' de

\footnotetext{
15 „Natürlich, sofort traten sie in Aktion mit Knüppeln und Fußtritten und warfen mich auf den Boden. Sie hielten mich fest, und ich wurde auf eine Holzpritsche gehoben, die sich auf der rechten Seite der Zelle befand, und mit dem Bauch nach unten gelegt. Sie streckten meine Arme und Beine in die Länge und fesselten mich an den Händen und Fußgelenken. Ein Posten drückte mir sein Knie in den Rücken, zwei andere hoben mir die gefesselten Arme nach hinten über den Kopf hinweg auf den Rücken, und zwei weitere machten das gleiche mit den Beinen. Der Offizier band dann mit einer weiteren Handschelle die Hände und Füße zusammen. Ich lag wie ein Schaukelpferd, nur noch die äußersten Rippenspitzen hatten Berührung mit der Pritsche. Wenn ich die Arme nach unten bewegte, gingen die Beine in die Höhe. Ich dachte, dass mir jeden Moment alle Knochen im Leibe brechen müßten. Der schlimmste Schmerz kam von den Rippen, wo die Haut sich rötete und abschürfte. Mit einer Stahlrute zwischen den Zähnen wurde ich zusätzlich noch geknebelt. Der Offizier zog mich an den Haaren nach vorne und sagte: "Wir haben Zeit, wir können warten.”
} 
realidade”. Se falarmos de uma “ética de representação”, sem dúvida, cabe plenamente a afirmativa proposta por SELIGMANN-SiLVA (1998: 22) de que "[e]ssa ética e estética da literatura de testemunho possui o corpo - a dor - como um dos seus alicerces”.

\section{Das prisões políticas na Zona de Ocupação Soviética e na RDA: "Uma boa luta"}

O terceiro exemplo de relatos sobre a violência contra dissidentes políticos na antiga RDA, selecionado para compor o presente quadro panorâmico, é o livro Ein guter Kampf. Fakten, Daten, Erinnerungen 1945-1954 (1998; “Uma boa luta. Fatos, datas, recordações 1945-1954”), de Ewald Ernst, autor, aliás, que consta também na coletânea Zeit-Zeugen (“'Testemunhos do tempo”) (CAMPHAUSEN 1996: 11-13). Conforme indicado por Brigitte Kaff na “Introdução” ao livro, Ewald Ernst, então com vinte e seis anos de idade, deputado estadual de Sachsen-Anhalt pelo CDU - ChristlichDemokratische Union (“União Democrata-Cristã”), foi detido em 16 de março de 1947, um domingo à noite, na cidade de Halle. Dois homens em trajes civis, portando revólveres, o arrastaram até um carro. Naquele momento, tinha início uma longa via crucis de sete anos por prisões da NKWD, a polícia secreta soviética, e pelo "Campo Especial” de Bautzen (cf. KAFF 1998: 7). Em suas memórias, Ewald Ernst retrata a vivência das prisões políticas na Zona de Ocupação Soviética e na RDA, valendo-se também de documentos e de cartas escritas durante o período em que esteve detido. Ele descreve a fase de reconstrução da Alemanha após o término da guerra, a luta dos jovens democratas contra a ditadura nos moldes stalinistas que começava a se impor na parte oriental do país, o início de sua atividade política enquanto deputado pelo CDU na Zona de Ocupação Soviética, bem como sua prisão, o período de averiguação nos porões das prisões de Potsdam e de Berlim-Hohenschönhausen, a condenação pelo Tribunal Militar soviético e o longo período de cumprimento da pena em Bautzen.

Nas eleições estaduais de 20 de outubro de 1946, Ewald Ernst foi eleito deputado pelo CDU e assumiu as funções de secretário e líder do partido na Câmara Estadual de Sachsen-Anhalt. A onda de prisões de políticos e pessoas ligadas ao CDU que ocorreram após as eleições e nos primeiros meses de 1947, aparentemente, foi motivada por diversos aspectos: desmantelamento dos grupos democráticos nas universidades e nas igrejas, sobretudo a JU - Junge Union (“União Jovem”); repressão

à "Inteligência”, isto é, aos potenciais críticos do comunismo; fortalecimento das 
organizações totalitárias, assegurando a soberania ao SED, com a fusão forçada dos partidos comunista e social-democrata, e à FDJ - Freie Deutsche Jugend ("Juventude Alemã Livre”), fundados no início de 1946; punição por contatos de toda natureza com amigos, partidos, instituições ou autoridades aliadas no setor ocidental (cf. KAFF 1998: 12-13).

Após ser transferido de Halle para a Prisão de Potsdam, na Lindenstrasse, Ewald Ernst foi interrogado pela primeira vez. Seu relato a respeito demonstra lacunas de memória e condensação de informações (ERNST 1998: 52):

[...] Não estou consciente de ter assinado algo em Potsdam. Espancado até sangrar, empurrado escada abaixo sem sentidos, para o porão, por horas a fio de pé, nu, na água, faminto após a retirada da alimentação: um tempo terrível em Potsdam, que mesmo após anos ainda desperta pesadelos. ${ }^{16}$

Podemos afirmar, a partir dessa passagem, que o relato não apenas se propõe como “testemunho” do vivenciado, como também é, na própria materialidade, “testemunho” do trauma, uma vez que, segundo Shoshana FELMAN (2000: 18):

[...] Como uma forma de relação com os eventos, o testemunho parece ser composto de pequenas partes de memória que foram oprimidas pelas ocorrências que não tinham se assentado como compreensão ou lembrança, atos que não podem ser construídos como saber nem assimilados à plena cognição, eventos em excesso em relação aos nossos quadros referenciais.

Esse é um aspecto importante a se destacar, pois, o relato de Ewald Ernst sobre cenas traumáticas é marcado predominantemente por concisão e lacunas. Trata-se daquela “[i]nsuficiência das palavras para nomear os fantasmas do horror”, de que nos fala Leonardo SENKMAN (2003: 248). Aliás, a cena traumática anteriormente citada era apenas a primeira estação de uma série de interrogatórios acompanhados de tortura. Em seguida, Ewald Ernst foi transferido para a prisão central de investigação sob administração da NKWD, em Berlim-Hohenschönhausen. Lá, ficou detido no chamado “U-Boot” (“submarino”), como era denominado o complexo de celas sem janela, nos porões da prisão. Assim como na passagem anterior, Ewald ERNST (1998: 55) descreve os interrogatórios de modo lapidar, através de apontamentos esparsos, sem elaborar um

16 „,...] Mir ist nicht bewusst, in Potsdam eine Unterschrift geleistet zu haben. Blutig geschlagen, besinnungslos die Kellertreppe hinuntergestoßen, Stunden nackt im Wasser stehend, hungrig nach Entzug der Verpflegung: Eine schreckliche Zeit in Potsdam, die noch nach Jahren Alpträume auslöst.“ 
texto propriamente dito, como se isso reproduzisse também no texto marcas do evento traumático:

Os interrogatórios aconteciam constantemente de madrugada em espaços de tempo muito variados. Só consigo descrever as condições em breves apontamentos:

- horas ou poucos minutos,

- interrogatório ou nenhuma palavra,

- permissão para sentar ou ficar de pé até desmaiar,

- solícito, mesmo amável ou tratando a socos e pontapés,

- oferta de uma refeição quente (para oficiais), de leitura ou promessas atreladas a condições,

- roupas de baixo, vestes a pedido fornecidas imediatamente ou recusadas, ou após algum tempo de espera (também quando da necessidade de pequenos medicamentos),

- condução de volta à cela em passo normal ou acelerado, sempre com as mãos algemadas,

- dependência total do oficial de interrogatório "pessoal”. ${ }^{17}$

O fato de não haver uma plena articulação discursiva dos eventos traumáticos demonstra que, como ressalta Jeanne Marie GAGNEBIN (2000: 106), “o problema maior da representação do horror” é “o de sua fundamental irrepresentabilidade, pois essa experiência sempre será incomensurável à sua tradução em palavras e conceitos”.

Durante vinte e um meses, Ewald Ernst esteve detido numa cela dos porões da Prisão de Hohenschönhausen, sempre negando as acusações de “espionagem” e “formação de grupo anti-soviético”. Seu estado de saúde tornou-se debilitado, sobretudo pela má alimentação e pela falta de acompanhamento médico, e a tuberculose se manifestou intensamente. Além disso, a depressão começou a dominá-lo. Em 13 de dezembro de 1948, Ewald Ernst foi condenado juntamente com outros seis colegas ligados ao CDU, detidos na mesma época que ele, a 25 anos de reclusão e trabalhos forçados.

17 „Die stets nächtlichen Verhöre fanden in höchst unterschiedlichen Zeitabständen statt. Nur in Stichworten vermag ich die Umstände zu beschreiben:

- Stunden oder wenige Minuten,

- Verhör oder kein Wort,

- Sitzen gestattet oder Stehen bis zur Ohnmacht,

- verbindlich, eher freundlich oder traktierend mit Faust oder Stiefel,

- Angebot eines warmen (Offiziers-)Essens, von Lektüre oder an Bedingungen geknüpfte Versprechungen,

- Wäsche, Kleidung auf Bitte sofort oder abgewiesen oder nach Wartezeit (auch bei Bedarf von kleinen Medikamenten),

- Rückführung in die Zelle in normaler Gangart oder im Laufschritt, immer mit Handfesseln,

- totale Abhängigkeit von dem "persönlichen” Vernehmungsoffizier.“ 
Logo depois da condenação, Ewald Ernst foi transferido para a Penitenciária de Bautzen II, em Sachsen. Construída entre 1900 e 1904, a Prisão de Bautzen foi batizada pelos prisioneiros de "Miséria Amarela” (“Gelbes Elend”) por seus tijolos amarelados. Em 1945, as autoridades soviéticas transformaram a prisão num "Campo de Internos e de Presos em Cumprimento Penal” (Internierten- und Strafgefangenen-Lager). Sua população carcerária variava entre 5.000 e 7.000 detentos (cf. ERNST 1998: 74). Ewald Ernst passou as primeiras semanas de sua detenção em Bautzen numa ala de tratamento médico, junto com cerca de 600 doentes. Seu estado de saúde se agravara consideravelmente, e o sofrimento e a morte de companheiros de infortúnio fizeram com que o desânimo o abatesse. A tentativa de reconstruir pela memória o vivenciado na sala de tratamento também é lacunar: “A recordação do decorrer do dia é pálida, reprimida. O esforço em manter a própria individualidade exigia muita força e empenho. O cuidado médico cabia a médicos alemães, não havia medicamentos disponíveis suficientes” (ERNST 1998: 75). ${ }^{18}$

Outro aspecto a se destacar no relato de testemunho de Ewald Ernst diz respeito às mudanças ocorridas durante o período em que esteve preso em Bautzen em termos de direção do sistema prisional. Em meados de fevereiro de 1950, as autoridades soviéticas passaram para o Ministério do Interior da RDA a responsabilidade de todas as prisões e campos. Em Bautzen, mais de 5.000 prisioneiros foram entregues à Polícia Popular (cf. ERNST 1998: 78-80). Porém, segundo Ewald ERNST (1998: 81), em termos práticos, não ocorreram mudanças significativas para melhoria no tratamento dos presos, o que gerou rebeliões em algumas unidades do campo:

A segunda rebelião de prisioneiros no dia 31 de março de 1950 foi sufocada a golpes de cassetete pela Polícia Popular. Mesmo no pavilhão II, o Major Schulz atacou com fúria, à frente de sua tropa. Eles não se intimidavam em soltar os cães das correias e atiçá-los contra os doentes. Ferimentos graves, agravamentos de doenças e até mesmo casos de morte foram as conseqüências. ${ }^{19}$

A maior parte de sua detenção em Bautzen Ewald Ernst passou no pavilhão III, onde os cuidados médicos eram melhores, tanto por parte dos médicos e enfermeiros,

18 „[...] Die Erinnerung an den Tagesablauf ist verblasst, verdrängt. Das Bemühen, die eigene Individualität zu bewahren, verlangte viel Kraft und Anstrengung. Die ärztliche Versorgung oblag deutschen Ärzten, Medikamente standen nicht ausreichend zur Verfügung.“

19 „Der zweite Häftlingsaufstand am 31. März 1950 wurde von der Volkspolizei brutal niedergeknüppelt. Selbst im Haus II wütete der Vopo-Major Schulz mit seiner Schlägertruppe. Sie schreckten nicht davon zurück, Hunde von der Leine zu lassen und sie auf die Kranken zu hetzen. Schwere Verletzungen, Krankheitsverschlechterungen und sogar Todesfälle waren die Folgen.“ 
quanto de outros prisioneiros, o que ajudou no tratamento da tuberculose. Ele foi libertado em 18 de janeiro de 1954, após a decisão do Governo da União Soviética em autorizar a libertação de presos políticos alemães que haviam sido condenados durante o período de administração soviética. Sua reabilitação ocorreu quarenta anos mais tarde, contemplado pela “Lei de Reabilitação das Vítimas de Repressões Políticas” (Gesetz zur Rehabilitierung der Opfer der politischen Repressionen) outorgada pela Promotoria Geral da Federação Russa em 30 de setembro de 1994 (cf. ERNST 1998: 101).

\section{Os arquivos da Stasi: a documentação da violência}

Todas as publicações apresentadas até aqui têm um aspecto formal em comum: elas contêm uma ampla documentação composta de fotos, protocolos de interrogatórios, documentos pessoais, relatórios, correspondências, etc. Grande parte dessa documentação se origina dos arquivos das instituições prisionais e dos autos da Stasi. Com a promulgação da Stasi-Unterlagen-Gesetz (“Lei da Documentação da Stasi”) em 10 de dezembro de 1992 e com a conseqüente criação da Behörde des Bundesbeauftragten für die Unterlagen des Staatssicherheitsdienstes der ehemaligen DDR (BStU - "Repartição do Encarregado Federal dos Documentos do Serviço de Segurança de Estado da antiga RDA”), os ex-cidadãos da RDA tiveram direito ao acesso aos autos pessoais que constavam nos arquivos da Stasi. Conforme ressalta Günter BuCHSTAB (1997: 7),

[a]pós o fim do regime, muitos cidadãos reivindicaram o direito de acesso aos autos. Eles queriam saber se entre amigos, colegas de trabalho ou até mesmo membros da família se encontrava um agente. Eles queriam saber o que os agentes haviam relatado e por que haviam feito isso. Para eles, mais precisamente, as vítimas, o acesso aos autos é um ato de libertação própria. ${ }^{20}$

A abertura desses arquivos revelou as dimensões assustadoras de um moderno sistema totalitário de controle e vigilância dos cidadãos: 90.000 funcionários oficiais, 173.000 agentes, delatores, colaboradores não-oficiais e outros tipos de colaboradores estiveram a serviço do Ministerium für Staatssicherheit (MfS - "Ministério de

\footnotetext{
20 „Viele Bürger beanspruchten nach dem Ende des Regimes das Recht auf Akteneinsicht. Sie wollten wissen, ob sich unter Freunden, Kollegen oder sogar Familienangehörigen ein Spitzel befand. Sie wollten wissen, was die Spitzel berichtet und warum sie es getan hatten. Für sie, die Opfer, ist die Einsicht in die Akten ein Akt der Selbstbefreiung.“
} 
Segurança do Estado”), para uma população de 17 milhões de habitantes; um arquivo com cerca de quatro milhões de dossiês sobre cidadãos da RDA, os quais abrangem uma grande parte da população (cf. BuCHSTAB 1997: 7). Como aponta Günter BUCHSTAB (1997: 9), “о acesso aos autos oferece a possibilidade de desmascarar a ditadura do SED por meio de seu próprio espólio sujo”. ${ }^{21}$ Para Joachim GAUCK (1997: 13), então encarregado federal dos documentos da Stasi, apenas por meio de fatos podese proceder contra a postura nostálgica em relação ao passado da RDA, de modo que a abertura dos autos significaria "um remédio contra a nostalgia de nossos conterrâneos”, 22 pois permitiria reconhecer "aquelas subestruturas, que o opressor, conscientemente, ocultara aos oprimidos” (GAUCK 1997: 20). ${ }^{23}$ Além disso, como destaca Roger EngELMANN (1997: 28), “[é] natural que documentos remanescentes de órgãos repressores sejam de grande significado justamente para o estudo de ditaduras e, naturalmente, também para o tratamento político e judicial de sua atuação”. ${ }^{24}$ Segundo ENGELMANN (1997: 37),

[...] [a]s informações obtidas pela Stasi, freqüentemente, sob violação massiva dos direitos fundamentais nos dá, hoje, justamente informações sobre aqueles fatos que eram desagradáveis para o regime, e que foram silenciados no interesse de sua própria estabilidade: fracassos, inconvenientes, falta de consenso e contradição. [...] ${ }^{25}$

Outro aspecto relevante sobre o acesso aos autos da Stasi é a oportunidade que as pessoas tiveram de conhecer o seu próprio passado, de saber o que era autêntico e o que era fabricado pelos agentes do Serviço de Segurança. Vera LENGSFELD (1997: 51), ativista na luta pelos direitos civis na RDA, vítima de vigilância e perseguição constante, afirma que "foi correto e importante, e até mesmo por necessidade terapêutica, abrir os autos da Stasi. Somente isso permitiu a muitas das pessoas

\footnotetext{
21 “[...] wie Akteneinsicht die Möglichkeit bietet, die Diktatur der SED anhand ihrer eigenen schmutzigen Hinterlassenschaft zu entlarven.“

${ }^{22}$ „eine Medizin gegen die Nostalgie unserer Landsleute.“

23 ,„[...] jene Substrukturen, die der Unterdrücker wohlwissend den Unterdrückten verborgen hatte.“

24, „[...] Es liegt in der Natur der Sache, dass Überlieferungen von Repressionsorganen gerade für die Erforschung von Diktaturen - und natürlich auch für die politische und justitielle Aufarbeitung ihres Wirkens - von herausragender Bedeutung sind. [...]“

25, „[...] Die von der Staatssicherheit häufig unter massiver Verletzung von Grundrechten erlangten Informationen geben uns heute gerade über jene Sachverhalte Auskunft, die dem Regime unangenehm waren und die es im Interesse seiner eigenen Stabilität totschwieg: Fehlentwicklungen, Missstände, mangelnder Konsens und Widerspruch. [...]“
} 
atingidas a possibilidade de, a posteriori, colocar ordem em suas vidas e se livrar de determinadas coisas bem ruins”. ${ }^{26}$

\section{A burocracia do Estado de vigilância e repressão: “A Stasi foi meu secretário"}

Nosso próximo exemplo de relatos sobre a violência contra opositores políticos na antiga RDA é um caso típico de tratamento do passado a partir do acesso aos autos da Stasi. Trata-se da obra Die Stasi war mein Eckermann oder: mein Leben mit der Wanze (1991; “A Stasi foi meu secretário ${ }^{27}$ ou: minha vida com a escuta”). Seu autor é o escritor Erich Loest, aliás, pseudônimo de Hans Walldorf, que nasceu em 1926 na pequena cidade de Mittweida, em Sachsen. Embora fosse filiado ao SED desde 1947, os acontecimentos de 17 de junho de 1953, quando trabalhadores foram às ruas para protestar contra o Governo da RDA, levaram Erich Loest a fazer inúmeras críticas ao regime do SED, como, por exemplo, a necessidade de uma “desestalinização" do Governo. Em 1957, o escritor foi expulso do partido, preso e condenado a sete anos e meio de detenção no Campo de Bautzen, onde cumpriu pena até 1964, sob a acusação de “formação de grupo contra-revolucionário" ("konterrevolutionäre Gruppenbildung”) ${ }^{28}$, além de ter tido todos seus bens confiscados. Em 1979, Erich Loest entrou novamente em conflito com as autoridades da RDA, ao se engajar, juntamente com outros escritores, numa ação de protesto contra a censura. Como conseqüência, ele passou a ser vigiado permanentemente pela Stasi, o que tornou insustentável a sua permanência na RDA. Em decorrência disso, ele transferiu-se em 1981 para a República Federal da Alemanha, após ter recebido uma permissão para viajar, e desde 1990 vive novamente em Leipzig, palco da maioria de seus romances que representam de modo crítico o cotidiano na RDA. Enquanto a maioria de suas obras anteriores à detenção em Bautzen defende a linha partidária do SED, as obras

\footnotetext{
26, „[...] war es richtig und wichtig und sogar von therapeutischer Notwendigkeit, die Stasi-Akten zu öffnen. Erst das hat vielen Betroffenen die Möglichkeit gegeben, im nachhinein Ordnung in ihr Leben zu bringen und ganz bestimmte schlimme Dinge auszuräumen.“

${ }^{27}$ Trata-se de um título irônico, pois Erich Loest menciona o nome de Johann Peter Eckermann (17921854), escritor alemão que atuou como secretário pessoal de Goethe a partir de 1823, auxiliando-o na publicação da Ausgabe letzter Hand (1823; “edição de última mão”), além de ter escrito e publicado a obra Gespräche mit Goethe in den letzten Jahren seines Lebens (1836-1848; “Conversas com Goethe nos últimos anos de sua vida").

${ }^{28}$ Cf. Erich Loest (verbete). In: http://www.dhm.de/lemo/html/biografien/LoestErich/; Acesso em 13 Ago. 2006.
} 
publicadas após sua libertação são eminentemente marcadas pelo tom de crítica à situação política da RDA e aos desmandos do SED. Em decorrência dos acontecimentos logo após a Queda do Muro de Berlim, Erich Loest foi reabilitado pelo Tribunal Superior de Justiça da RDA em abril de 1990. Após ter acesso aos autos pessoais nos arquivos da Stasi e tomar conhecimento da dimensão da vigilância e espionagem à qual fora submetido, Erich Loest publicou duas obras que tratam do tema: uma ficcional, o romance Froschkonzert (1990; “Concerto do Sapo”) e outra baseada na documentação encontrada, exatamente Die Stasi war mein Eckermann oder: mein Leben mit der Wanze (1991; “A Stasi foi meu secretário ou: minha vida com a escuta”). De acordo com a documentação, suas conversas privadas foram gravadas e toda a sua correspondência, controlada e registrada. Hoje, para as novas gerações, o escritor se tornou uma espécie de símbolo da antiga resistência contra o regime do SED. Recordar o passado da RDA, para Erich Loest, é falar de uma situação traumática.

Além disso, falar da referida obra de Loest é falar também, mesmo que brevemente, da documentação da Stasi sobre sua pessoa, de como ele foi vigiado e teve até mesmo seu telefone grampeado. O dossiê do serviço secreto, no qual o escritor figura com o codinome “autor II”, remonta ao período de 1975 a 1982 e contém trinta e uma pastas classificadoras com cerca de 300 páginas cada uma, utilizadas como fonte para redação do livro. Na referida documentação, encontram-se relatórios de escuta telefônica, resoluções, telegramas, relatórios de agentes e informações coletadas que as divisões 26A e 26B da Stasi em Berlim e em Leipzig haviam colecionado e arquivado (cf. LOEST 1991: 9-11).

O livro Die Stasi war mein Eckermann oder: mein Leben mit der Wanze está estruturado em três partes: "Der Schatz hinter der Mülltone” (“O tesouro atrás da lata de lixo”), “Aus meiner Stasi-Akte” (“De meus autos da Stasi”), e “Nachspiele” (“Epílogos”). Na primeira parte (LOEST 1991: 7-16), o escritor relata, basicamente, sobre o modo como tomou conhecimento da existência de vasta documentação sobre sua pessoa nos arquivos da Stasi, e sobre o desconhecimento da dimensão da vigilância à qual fora, secretamente, submetido. A segunda parte, a mais longa das três, contém uma seleção de textos de 35 documentos do serviço secreto sobre Erich Loest, correspondentes ao período de 1975 a 1981 (LOEST 1991: 17-118). Nela, o autor deixa que os próprios documentos “falem”, revelando o jargão burocrático de um Estado que submetia cidadãos à vigilância permanente. Finalmente, a terceira parte (LOEST 1991: 
119-154) trata da repercussão e dos desdobramentos da descoberta dos documentos, através de cartas e de matérias de jornal dos anos de 1990 e 1991, que noticiam, por exemplo, a acusação formal efetuada por Erich Loest contra Dietmar Keller, exMinistro da Cultura da RDA (LOEST 1991: 149-151).

O caso Erich Loest é típico para aquelas pessoas que, após terem conhecimento dos conteúdos de seus autos da Stasi puderam reconstituir suas vidas e perceber a dimensão com que eram controladas e vigiadas, não só por agentes oficiais, mas também por vizinhos, IMs (IM - Inoffizieller Mitarbeiter; “colaborador informal”), colegas, que muitas vezes se sujeitavam a isso para tirar algum tipo de proveito. Um dos documentos, assinado por um certo capitão Baumheier, atesta a burocracia em torno da decisão de se vigiar o escritor (LOEST 1991: 12):

Correspondendo ao emprego de tarefas do plano operativo da Divisão Central XX de 10 de agosto de 1978, o Loest, Erich está sendo trabalhado por nossa unidade do Serviço de Segurança, uma vez que, correspondendo à sua orientação fundamentalmente dissidente através de publicações na RDA e na BRD, ele ataca âmbitos sociais essenciais de nosso desenvolvimento socialista. $[\ldots]^{29}$

Um dos inúmeros documentos expedidos pela Divisão XX da Stasi, datado de 17 de outubro de 1979 e registrado com o número 5004/79, informa sobre o contato que Erich Loest teria com Lind, uma médica do Hospital de Psiquiatria, o que indica que ambos estariam sendo vigiados (LOEST 1991: 58):
A médica do HP de Psiquiatria, Lind, e seu esposo mantêm contato pessoal com o escritor dissidente e negativo Loest, Erich, que está sendo trabalhado num $\mathrm{P}$ [rocessamento] O[perativo].
Numa conversa, em 04/10/79, Lind se expressou negativamente sobre a política cultural da RDA e declarou-se solidária a Loest e a seu posicionamento sobre a política cultural.
Nós solicitamos tomar conhecimento desse fato.
Oficialmente, essa informação não pode ser explorada.
Diretor de Divisão
Wallner
Tenente-Coronel $^{30}$

\footnotetext{
29 „Entsprechend der Aufgabenstellung aus dem Operativ-Plan der Hauptabteilung XX vom 10. August 78 wird durch unsere Diensteinheit der Loest, Erich, bearbeitet, da er entsprechend seiner feindlichen Grundeinstellung durch literarische Veröffentlichungen in der DDR und der BRD wesentliche Bereiche unserer sozialistischen Entwicklung angreift. [...]“

${ }_{30}$ „Die Ärztin des BHK für Psychiatrie, Lind, und Ihr Ehemann unterhalten persönliche Kontakte zu dem in einem OV bearbeiteten feindlich-negativen Schriftsteller Loest, Erich.
} 
Além da diversidade da documentação que se encontra nos autos do escritor relatórios de informantes, cartas, telegramas, relatórios de escutas etc. -, os temas são igualmente diversificados, predominando, entretanto, assuntos ligados às atividades no cenário literário e na Associação dos Escritores da RDA, bem como às tentativas de Erich Loest de publicar no exterior seus textos censurados.

\section{A memória "anti-ostálgica” da infância e da juventude na RDA: "Nascido em 13 de agosto"}

Uma última categoria a se considerar, ainda, com relação às possibilidades de se rememorar o passado traumático na RDA de maneira crítica pode ser ilustrada com a obra Geboren am 13. August. Der Sozialismus und ich (2004; "Nascido em 13 de agosto. O socialismo e eu”), de Jens Bisky, jornalista e redator do Süddeutsche Zeitung. Trata-se de um caso sui generis, pois seu autor recorda, de maneira crítica, sua infância e juventude na RDA, vivenciada dentro do círculo da elite política do país, sem ter passado pela vivência traumática das prisões, como os autores anteriormente apresentados. "Nascido em 13 de agosto” é uma obra autobiográfica de Jens Bisky (*1966), filho do político Lothar Bisky (*1941), presidente do PDS - Partei des Deutschen Sozialismus ("Partido do Socialismo Alemão”) que para muitos significou uma continuidade ideológica do SED após a Reunificação alemã. Nascido em 13 de agosto de 1966, portanto, no dia em que se comemorou o $5^{\circ}$ aniversário da construção da chamada "Parede de Proteção Antifascista" (Antifaschistischer Schutzwall), no jargão oficial, Jens Bisky responde à “ostalgia”, ou seja, à “nostalgia pela Ostdeutschland / Alemanha Oriental”, a qual, segundo o escritor, em entrevista concedida ao canal de televisão alemão Deutsche Welle, acabou “Ihe dando nos nervos”, pois “o socialismo, tanto para seus defensores quanto para seus opositores, se tratava de algo muito sério e, em certas situações, um caso de vida ou morte”. ${ }^{31}$ Jens Bisky critica,

Bei einem Gespräch am 4.10.79 sprach sich die Lind negativ zur Kulturpolitik der DDR aus und erklärte sich solidarisch mit Loest und dessen Einstellung zur Kulturpolitik.

Wir bitten um Kenntnisnahme.

Offiziell kann diese Information nicht ausgewertet werden.

Leiter der Abteilung

Wallner

Oberstleutnant“

${ }^{31}$ Entrevista (não publicada) com Jens Bisky sobre o tema Keine Ostalgie, bitte! ("Nenhuma ostalgia, por favor!”), exibida no programa Kultur 21, da Deutsche Welle, em outubro de 2004, por ocasião do 
além disso, o tom de humor com que o cotidiano na RDA tem sido retratado tanto em romances quanto em filmes, ${ }^{32}$ ressaltando, ao contrário, os traços violentos e repressivos, constitutivos do regime do SED. Ele chama a atenção, por exemplo, para o emprego de uniformes da FDJ - Freie Deutsche Jugend (“Juventude Livre Alemã”) descontextualizados de sua funcionalidade, ou seja, destinados para uso em paradas públicas, e não, inocentemente, no âmbito privado. Sua obra retrata, sobretudo, o bairro berlinense de Marzahn e suas “Plattenbauten” (blocos de prédios construídos segundo a arquitetura adotada pelo Estado socialista), para onde a família se mudou quando Jens Bisky ainda era adolescente, proveniente de Leipzig. Participação ativa na FDJ, filiação ao SED, ingresso na academia militar da NVA são algumas de suas estações, sempre apresentadas a partir de uma postura intimista.

Podemos dizer que, partindo de um olhar retrospectivo, Jens Bisky se despede de sua infância e juventude "planejada” pelos pais na antiga RDA. E tal despedida não se realiza de modo conciliatório, mas sim extremamente crítico, onde o autor não poupa o Estado, a família, e nem a si próprio (BISKY 2004: 14-15):

\begin{abstract}
Minha relação com a RDA se transformou ininterruptamente. No verão de 1983, eu defendia o país incondicionalmente. Incomodava-me apenas o passo do caracol, no qual o processo mundial revolucionário avançava e a sociedade socialista se desenvolvia. Eu vivia num reino de espíritos, no qual valia o mandamento do cumprimento do dever e se acreditava na força curativa de citações de Marx. Embora a palmatória com o martelo e a foice pareça ridícula, ela possuía um sentido. Afinal, foi prometido que o homem se tornaria homem pleno, desfrutando o belo, um ser igual entre iguais. Acima do reino dos espíritos surgia a lua da redenção e o mergulhava em luz sedutora. Lá estava Wladimir Iljitsch Uljanow ao lado de Pablo Picasso, a partisã soviética Soja
\end{abstract}

\footnotetext{
lançamento de seu livro Geboren am 13. August. Der Sozialismus und ich (2004): „Mir ist diese ganze Ostalgie-Welle ungeheuer auf die Nerven gegangen und aus mehreren Gründen. Der eine Grund ist, dass der Sozialismus sowohl für seine Anhänger wie für seine Gegner eine sehr ernsthafte, manchmal eine todernste Sache war. In diesen Ostalgie-Büchern und auch in Filmen erscheint er immer als sehr lustig und sehr heiter. Also diese Blaue-Hemde-Pionier-Uniformen sind für Massenaufmärsche entworfen, nicht dafür, dass man am Küchentisch irgendwie Spass miteinander hat." Informações complementares exibidas ao final da entrevista: Bericht: Ch. Thälmann, M. Tischer; Kamera: Hans-Jürgen Leikauf; Schnitt: Matthias Spranger.

${ }^{32}$ Exemplos de "ostalgia" na Literatura e no Cinema são o romance Am kürzeren Ende der Sonnenallee (1999; "No extremo mais curto da Alameda do Sol”; título brasileiro: O charuto apagado de Churchill, tradução. de Marcelo Backes, Porto Alegre, L\&PM, 2005), de Thomas Brussig e, respectivamente, os filmes Sonnenallee (1999; “Alameda do Sol”), de Leander Haußmann, e Kleinruppin forever (2004; "Kleinruppin para sempre"), de Carsten Fiebeler. A eles se opõem criticamente os romances Froschkonzert (1990; “Concerto do Sapo") e Nikolaikirche (1995; "Igreja de São Nicolau”), de Erich Loest, e os filmes Nikolaikirche (1995; "Igreja de São Nicolau”) de Frank Beyer, Der Tunnel (2001; “O túnel”), de Roland Suso Richter, e Das Leben der Anderen (2006; “A vida dos outros”), de Florian Henckel von Donnersmarck, vencedor do Oscar de melhor filme estrangeiro em 2006 (cf. CORNELSEN, 2007: 82-97; CORNELSEN 2008a: 115-119; CORNELSEN, 2008b: 137-184).
} 
Kosmodemjanskaja ao lado da sagrada Rosa Luxemburgo, Júri Gagarin ao lado de Ângela Davis, e eles miravam felizes a atividade dos Jovens Pioneiros, dos camponeses da LPG e dos agitadores da FDJ. ${ }^{33}$

Num tom irônico, ao recordar de sua adolescência, Jens Bisky estiliza a sua própria crença na ideologia então reinante como uma religião, a qual deveria culminar com a redenção do "homem pleno”. Com seu livro o autor se propõe a apresentar uma imagem da RDA construída a partir de suas recordações (BISKY 2004: 16):

Aqui, o Estado dos operários e camponeses aparece no espelho convexo de minhas recordações: no crescer com ideais, ilusões, erros, e na lenta despedida deles. Aspectos pessoais e políticos, para mim, estão entretecidos de modo indissociável, se eu quiser relatar francamente sobre meu caso exemplar de uma juventude planejada. Aquele que hoje narra sobre a RDA faz bem em se posicionar de um lado, ao se decidir se fala do mundo dos aparatos estatais ou da vida dos alemães orientais, como criança, agente ou vítima, ao descrever a frieza dos funcionários ou o calor nos nichos, a repressão ou o aconchego. Eu não consigo separar as coisas assim tão nitidamente. Eu vivi vinte e três anos de minha vida entre aparato e sociedade, entre dominantes e dominados. ${ }^{34}$

Esse é um fator que empresta força ao relato de Jens Bisky, uma vez que, como o próprio escritor reconhece, não se trata de separar um determinado lado, mas sim de narrar sua vivência num estado totalitário, onde sociedade e Estado estavam entretecidos por uma série de organizações que eram, ao mesmo tempo, domesticadoras e domesticadas. Isso se reflete na trajetória de Jens Bisky, de Jovem Pioneiro, de agitador da FDJ, e de cadete da Escola de Oficiais da NVA - Nationale Volksarmee (“Exército Popular Nacional”), na qual atingiu o posto de Segundo-Tenente.

\footnotetext{
33 „Mein Verhältnis zur DDR hat sich ununterbrochen gewandelt. Im Sommer 1983 habe ich das Land bedingungslos verteidigt. Mich störte allein der Schneckengang, in dem der revolutionäre Weltprozess voranschritt und die sozialistische Gesellschaft sich entwickelte. Ich lebte in einem Geisterreich, in dem das Gebot der Pflichterfüllung galt und an die Heilkraft von Marx-Zitaten geglaubt wurde. Obwohl das Fuchteln mit Hammer und Sichel im Rückblick skurril wirkt, besaß es einen Sinn. Versprochen war, dass der Mensch ganz Mensch werde, Genießer des Schönen, ein Gleicher unter Gleichen. Über dem Geisterreich schien der Mond der Erlösung und tauchte es in verführerisches Licht. Da stand Wladimir Iljitsch Uljanow neben Pablo Picasso, die sowjetische Partisanin Soja Kosmodemjanskaja neben der heiligen Rosa Luxemburg, Juri Gagarin neben Angela Davis, und sie sahen erfreut auf das Treiben der Jungpioniere, LPG-Bauern und FDJ-Agitatoren.“

34 „Hier erscheint der Arbeiter- und Bauernstaat im Zerrspiegel meiner Erinnerungen: an das Aufwachsen mit Idealen, Illusionen, Irrtümern und den langsamen Abschied von ihnen. Persönliches und Politisches sind für mich unauflösbar verwoben, wenn ich aufrichtig über mein Fallbeispiel einer Jugend nach Plan berichten will. Wer heute von der DDR erzählt, tut gut daran, sich auf eine Seite zu schlagen, sich zu entscheiden, ob er von der Welt der Apparatschiks oder dem Leben der Ostdeutschen spricht, als Kind, als Täter oder als Opfer, ob er die Kälte der Funktionäre oder die Wärme in den Nischen beschreibt, Repression oder Geborgenheit. So säuberlich kann ich nicht trennen. Auf der Grenze zwischen Apparat und Gesellschaft, zwischen Herrschenden und Beherrschten habe ich dreiundzwanzig Jahre gelebt.“
} 
Por sua vez, a base documental para seu relato são os diários que os "pioneiros” escreviam - o "livro azul” Räte-ABC (“ABC dos Conselhos”), seus boletins escolares, e a observação atenta do que se passava em torno de si, dos professores, colegas de classe e familiares. Embora o discurso ideológico se revele na forma como Jens Bisky relata sobre sua infância e juventude, seja no âmbito familiar, seja na escola, projetando no foco narrativo um olhar adequado à faixa etária, o caráter repressor do regime do SED não deixa de ser notado, embora sem grande consciência, como é o caso do desaparecimento de Robert, um colega de escola, cujos pais foram detidos por suspeita de espionagem para o serviço secreto da Alemanha Ocidental (BISKY 2004: 52-53), ou mesmo quando sua mãe, que trabalhava como Dirigente de Setor “Política de Arte” em Berlim, fez-lhe revelações sobre sua atividade junto à Stasi (BISKY 2004: 57):

\begin{abstract}
Após a Virada, minha mãe me contou que, no final dos anos 70 , ela teria assinado uma declaração de compromisso do Ministério de Segurança do Estado. Em 1992, foi publicado no jornal Bild que ela era IM [i.e., "Inoffizielle Mitarbeiterin", "colaboradora informal”], e que escreveu relatórios, também sobre pessoas, as quais cumprimentaram o então adolescente Jens, ávido por aventuras. Essa é sua história, mas ela se afasta diante de minhas recordações dos tempos de Leipzig. ${ }^{35}$
\end{abstract}

Portanto, ao recordar-se de seu passado na RDA, Jens Bisky traz para dentro de seu relato a vivência de outros - como no exemplo acima, o de sua mãe, que chegou a fornecer à Stasi informações sobre o escritor Erich Loest -, porém, suas memórias permanecem decisivas na construção da imagem de uma RDA singular, erigida exclusivamente por suas recordações. Isso se torna evidente quando ele narra sobre relatos de outros alunos mais velhos, que se recordavam de ações repressivas na escola (BISKY 2004: 42):

Os mais velhos conseguem se lembrar que policiais ou agentes do Serviço de Segurança do Estado apareciam em sua classe, e que amigos desapareceram por anos porque eles pertenciam à organização Comunidade Jovem. Algo assim não ocorreu na minha RDA. Tampouco vivenciei a repressão brutal em meu tempo de escola, bem como insubordinação explícita. [...] ${ }^{36}$

35 „Nach der Wende erzählte mir meine Mutter, dass sie Ende der siebziger Jahre eine Verpflichtungserklärung des Ministeriums für Staatssicherheit unterschrieben habe. 1992 stand es in BILD. Sie war IM und schrieb Berichte, auch über Leute, die dem abenteuerlustigen Teenie Jens damals die Hand gegeben haben. Das ist ihre Geschichte, aber sie schiebt sich vor meine Erinnerungen an die Leipziger Zeit.“

36 „Ältere können sich daran erinnern, dass Polizisten oder Staatssicherheitsleute in ihrer Klasse erschienen sind und Freunde auf Jahre verschwanden, weil sie der Jungen Gemeinde angehörten. So 
Em “sua RDA”, o país de sua infância e juventude, em seu pequeno mundo idílico da elite do regime do SED, a repressão parecia aparentemente ausente, pelo menos em suas recordações. Mesmo quando os pais se manifestavam sobre a violência na RDA, a recordação está perpassada de ironia, onde o Estado totalitário adquire o status de “religião” política (BISKY 2004: 95):

Meus pais nunca justificaram os mortos do Muro e as proibições, mas sim os esclareceram. Com freqüência, eles vociferavam contra funcionários tolos, indiscretos e parasitas. Era como se eu fosse membro de uma igreja: se você está insatisfeito com o pároco, então, tente mudá-lo. Ou se torne você mesmo pároco, para que a Igreja comunista se consolide. Não criticar, fazer melhor! ${ }^{37}$

Além disso, ao rememorar a fase de transição política que culminou com a Reunificação alemã, Jens BISKY (2004: 220) ressalta não só a importância do processo de rememoração do vivenciado, mas também de tudo aquilo que veio à tona, cujos fatos as pessoas, até então, desconheciam:

[...] Em poucos meses, tudo o que parecia importante, ameaçador, emparedado por todos os tempos se dissipou. Riamos de nós próprios, do fato de que nós tínhamos levado isso a sério. Nos anos seguintes, nós ficaríamos sabendo de tanta coisa sobre a RDA que o riso, aos poucos, se desvaneceu em mim. ${ }^{38}$

E nesse processo de revelação posterior, tanto depoimentos de agentes e vítimas quanto a documentação gerada durante décadas por um Estado totalitário permitiu - e ainda permite - que a própria história da RDA seja reescrita, inserindo em si própria as escritas da violência cometida em seu nome. Mas isso não impede que o próprio escritor reflita sobre a forma como procurou se isolar da presença de um Estado que se pretendia onipresente através de seus aparelhos repressores e ideológicos (BISKY 2004: 237): “Em meus dias de RDA, o aparelho de delação e vigilância me parecia distante, situado num

etwas ist in meiner DDR nicht vorgekommen. Brutale Repression habe ich in meiner Schulzeit so wenig erlebt wie offene Aufsässigkeit. [...]“

37 „Mauertote und Verbote haben meine Eltern nie gerechtfertigt, aber erklärt. Viel wurde auf dumme Funktionäre, Schwätzer und Schmarotzer geschimpft. Es war, als wäre ich Mitglied einer Kirche: Wenn du mit dem Pfarrer unzufrieden bist, dann versuche, ihn zu ändern. Oder werde selber Pfarrer, damit die kommunistische Kirche gefestigt wird. Nicht meckern, besser machen!“

38, „.... In wenigen Monaten hatte sich alles, was wichtig, bedrohlich, festgemauert für alle Zeiten schien, aufgelöst. Es war ein Lachen über uns selber, dass wir das ernst genommen hatten. In den kommenden Jahren sollten wir so viel über die DDR erfahren, dass mir das Lachen allmählich verging.“ 
outro país. A gente podia reprimir bem a Stasi na vida cotidiana”. ${ }^{39}$ Consciente do próprio conflito com o passado na RDA, Jens BISKY (2004: 238-239) chama a atenção para o fato de que, nesse caso, a própria memória não dá conta do “real”, não apenas no sentido da lacuna e do apagamento pela exposição a um dado evento traumático, mas de fato lacunar pela falta da outra “memória” de ordem documental:

Entretanto, o aparelho criminoso, que unia delação, controle, desagregação, corrupção e terror, está bem investigado. Cada um pode saber como ele funcionava. Muitos conhecem o sentimento de ser expropriado biograficamente. A recordação de partes da própria vida ilude, é incompleta. O que se pensava, outrora, sobre amigos e colegas não estava certo. A traição produz um insípido vazio. $^{40}$

Ao concluir suas memórias, Jens Bisky não deixa de torná-las relativas, de não apontá-las como a "verdade” inconteste. Pelo contrário, o processo de rememoração parece estar, nesse caso, ligado a um desejo do escritor em fazer as pazes com o passado, sem deixar de ser crítico, indo assim numa direção contrária à “ostalgia”. Para ele, a escritura do passado da RDA, que inclui em si também as escritas da violência, é um processo complexo e, ao mesmo tempo, diverso em possibilidades, onde não caberiam apenas as certezas (BISKY 2004: 252-253):

[...] Mas se alguém, hoje, me acusar de ter transfigurado a RDA ou de ter pintado seu quadro num tom negro demais, que eu seria de esquerda demais ou de direita demais, comportado demais ou atrevido demais, acomodado demais ou distanciado demais, que minha imagem da República Federal seria rosa demais ou cinza demais, que eu usaria as roupas erradas ou daria muito valor ao consumo, que eu seria oriental demais ou ocidental demais, ou simplesmente desarraigado, então me ocorre sempre apenas a frase de um amigo americano: "It’s a free country”, este é um país livre - e o resto é incerto. ${ }^{41}$

\footnotetext{
39, „[...] In meinen DDR-Tagen schien mir der Spitzel- und Überwachungsapparat fern, in einem anderen Land gelegen. Man konnte die Stasi gut verdrängen im Alltagsleben.“

${ }^{40}$ „Inzwischen ist der verbrecherische Apparat, der Spitzelei, Kontrolle, Zersetzung, Wirtschaftskriminalität und Terror verband, gut erforscht. Jeder kann wissen, wie er funktionierte. Viele kennen das Gefühl, biographisch enteignet zu sein. Die Erinnerung an Teile des eigenen Lebens trügt, ist unvollständig. Was man über Freunde, Kollegen damals dachte, stimmte nicht. Verrat erzeugt eine schale Leere.“

${ }^{41}$ „,.... Aber wenn mir heute einer vorwirft, ich verklärte die DDR oder ich malte ihr Bild zu schwarz, ich sei zu links oder zu rechts, zu brav oder zu rotzig, zu angepasst oder zu distanziert, mein Bild der Bundesrepublik sei zu rosig oder zu grau, ich trüge die falschen Klamotten oder legte zu viel Wert auf Konsum, ich sei zu sehr Ossi oder zu sehr Wessi oder überhaupt wurzellos, dann fällt mir immer nur der Satz eines amerikanischen Freundes ein: "It's a free country", es ist ein freies Land - und der Rest ist ungewiss.“
} 
Entretanto, nos “Agradecimentos” (Danksagung), após ter apresentado em vinte capítulos sua vivência da RDA, dos anos 70 até seu fim, e mesmo os primeiros catorze anos da Alemanha pós-reunificada, Jens BISKY (2004: 255) revela ao leitor que sua narrativa memorialista está intencionalmente perpassada por certo caráter ficcional: “Recordações são ilusórias. Eu me esforcei em não atenuar nada; mas, por questões de proteção à pessoa, alterei e condensei detalhes”. ${ }^{42}$

\section{Considerações finais}

As cinco obras analisadas que compõem o quadro panorâmico apresentado nos permitem algumas considerações finais em relação ao modo como seus autores procuram lidar, após a Queda do Muro de Berlim, com o passado na República Democrática Alemã. Sem dúvida, todas elas se pautam por um tom decididamente crítico frente aos desmandos num Estado totalitário. “Transpor muros”, desse ponto de vista, implica um olhar memorialista de denúncia contra o esquecimento frente a um passado traumático.

Entretanto, as obras analisadas revelam também aspectos que as diferenciam entre si. As três primeiras delas, de maneira unívoca, podem ser subsumidas sob o conceito de "literatura de trauma" e, de um modo restrito, como exemplos de "escritas da violência”, uma vez que o trauma se revela tanto nos relatos, em termos de conteúdo, quanto na própria materialização discursiva através da linguagem. Seus autores (Weber, Zilli, Ernst) vivenciaram as prisões da RDA e prestam testemunho, como superstes, sobreviventes, e como testis, num “enfrentamento por assim dizer ‘jurídico’ com o real”, como define SELIGMANN-SILVA (2003: 387).

Outro grupo diferenciado de obras (Zilli, Ernst, Loest) se forma a partir do critério de associação entre o relato e o documento. Nesse caso, o diálogo entre relato e documento não se estabelece apenas no sentido de legitimação na busca por “verdade”, uma exigência de todo relato de testemunho, mas também passa por uma postura ética. Ética, na medida em que estabelece uma relação entre o sujeito que vivenciou a catástrofe e a necessidade de dar um testemunho do "real" dessa vivência, mesmo que esse “real”, de antemão, seja o "real perpassado pelo trauma”. E isso torna necessária,

\footnotetext{
42 „Erinnerungen sind trügerisch. Ich habe mich bemüht, nichts zu beschönigen, aus Gründen des Persönlichkeitsschutzes aber Einzelheiten verändert und verdichtet.“
} 
também, uma “ética da escritura”, como nos lembra SELIGMANN-Silva (2005: 85): “o testemunho impõe uma crítica da postura que reduz o mundo ao verbo, assim como solicita uma reflexão sobre os limites e modos de representação”. Como pudemos constatar, outro aspecto relevante no diálogo entre relato e documento é justamente o fato de que, com a abertura dos arquivos da Stasi, as pessoas puderam ter dimensão do grau em que estavam sendo vigiadas e de como as suas relações nos círculos familiares, profissionais e de amizade poderiam ter estado minadas pela onipresença do Estado totalitário, de modo que, nos relatos, há uma complementaridade entre a narrativa da experiência individual e a documentação gerada pelas instâncias de censura e repressão.

O caso Loest é emblemático nesse sentido, pois foi alguém que conheceu as prisões da RDA e que, mais tarde, seria vítima de vigilância implacável, até se transferir para a Alemanha Ocidental. Sua obra se diferencia das demais, pois não é o escritor, mas sim os documentos que "falam”, e no melhor jargão burocrático do "Estado dos operários e camponeses”. Portanto, se não tomarmos de modo restrito o conceito de “escritas da violência”, podemos considerar a obra de Loest um exemplo da “documentação da violência” pela escrita oficial do Estado totalitário.

Além disso, o texto de Erich Loest se diferencia significativamente dos demais textos analisados, pois não se orienta pelo relato de testemunho strictu sensu (Weber, Zilli, Ernst), bem como pelo relato autobiográfico de cunho memorialista (Bisky). Sua essência é de caráter documental, e o "relato" biográfico, nesse caso, se configura a partir de diversos documentos da burocracia de vigilância e repressão do Estado do SED. Esses documentos dos arquivos da Stasi, por assim dizer, auxiliam o escritor na elaboração de sua biografia, sendo que esta não nasce de sua enunciação propriamente dita, fruto da vivência, mas sim de procedimentos adotados pelo Ministério de Segurança da RDA no intuito de persegui-lo e de mantê-lo sob vigilância. Mas os documentos vão muito além, pois não apenas possibilitam a Erich Loest a construção de sua biografia a partir de informações desconhecidas até a descoberta de sua existência nos arquivos da Stasi, como também evidenciam a mentalidade daqueles que o perseguiam.

Por fim, consideramos a singularidade do olhar memorialista numa das obras (Bisky) uma outra forma de “escrita da violência”, se, naturalmente, não tomarmos esse conceito de modo restrito. Pois o texto de Jens Bisky não se enquadra na "literatura de trauma”. Todavia, não é menos contundente na crítica que faz ao antigo regime do SED, 
e não deixa de apontar um outro tipo de “violência”, muito mais sutil, diluída no dia-adia, na família, na escola, nas organizações partidárias, nas instituições militares, tornando onipresente o jugo de um Estado de vigilância e controle, que nos quarenta anos de sua existência adotou o conceito de “democrático”, que levava em seu nome, de uma maneira nada lisonjeira.

\section{Referências bibliográficas}

BiSKY, Jens. Geboren am 13. August. Der Sozialismus und ich. Berlin, Rowohlt, 2004.

Buchstab, Günter. Zur Einführung. In: Ahrberg, Edda (et al.). Die Akten und die Wahrheit. Coleção “Aktuelle Fragen der Politik”, n 49, Sankt Augustin, KonradAdenauer-Stiftung, 1997, 7-10.

CAMPhausen, Gabriele. "Zeit-Zeugen". Inhaftiert in Berlin-Hohenschönhausen. Berlin, Westkreuz-Druckerei, 1996.

CoRnelsen, Elcio Loureiro. A imagem de Berlim na literatura e no cinema. In: Forum Deutsch (12), Rio de Janeiro, 2008a, 102-128.

CORNELSEN, Elcio Loureiro. “Dominando o passado”. A imagem da RDA na Literatura e no Cinema Alemães após a Queda do Muro. In: UMBACH, Rosani Ketzer (org.). Memórias da repressão. Santa Maria/RS, UFSM / PPGL-Editores, 2008b, 137-184.

CORNELSEN, Elcio Loureiro. O espaço da interdição interditado pela nostalgia e pelo riso: o Muro de Berlim e a "Alameda do Sol”. In: Aletria (15), Belo Horizonte, 2007, 82-97. [artigo também disponível online: http://www.letras.ufmg.br/poslit/08_publicacoes_txt/ale_15/ale15_elc.pdf]

Engelmann, Roger. Die Unterlagen des MfS. Ihr Wert als historische Quelle. In: Ahrberg, Edda (et al.). Die Akten und die Wahrheit. Coleção "Aktuelle Fragen der Politik”, nº 49, Sankt Augustin, Konrad-Adenauer-Stiftung, 1997, 27-37.

Erich Loest (verbete). In: http://www.dhm.de/lemo/html/biografien/LoestErich/. (Acesso em 13 Ago. 2006).

Erler, Peter / KnABe, Hubertus. Der verbotene Stadtteil: Stasi-Sperrbezirk BerlinHohenschönhausen. $3^{\text {a }}$ ed., Berlin, Jaron-Verlag, 2008.

ERNST, Ewald. Ein guter Kampf. Fakten, Daten, Erinnerungen 1945-1954. Sankt Augustin, Academia-Verlag, 1998.

FELman, Shoshana. Educação e crise ou As vicissitudes do ensinar. In: Nestrovski, Arthur / Seligmann-Silva, Márcio (orgs.). Catástrofe e representação. São Paulo, Escuta, 2000, 13-71. 
GagneBin, Jeanne Marie. Palavras para Hurbinek. In: NeSTRovsKi, Arthur / SEligmann-Silva, Márcio (orgs.). Catástrofe e representação. São Paulo, Escuta, 2000, 97-110.

GAUCK, Joachim. Die Akten und die Wahrheit. Fünf Jahre Stasi-Unterlagen-Gesetz. In: Ahrberg, Edda (et al.). Die Akten und die Wahrheit. Coleção "Aktuelle Fragen der Politik”, nº 49, Sankt Augustin, Konrad-Adenauer-Stiftung, 1997, 11-26.

KAFF, Brigitte. Einleitung. In: ERNST, Ewald. Ein guter Kampf. Fakten, Daten, Erinnerungen 1945-1954. Sankt Augustin, Academia-Verlag, 1998, 7-13.

LAMBECK, Silke. Herr Brussig, was halten Sie von Nostalgie? (entrevista com Thomas Brussig). In: Berliner Zeitung, de 6/7 de novembro de 1999. http://www.thomasbrussig.de/interviews/berliner.htm (13/11/2006).

LENGSFELD, Vera. Verfolgung und Überwachung. Ein biographischer Rückblick. In: Ahrberg, Edda (et al.). Die Akten und die Wahrheit. Coleção "Aktuelle Fragen der Politik”, n 49, Sankt Augustin, Konrad-Adenauer-Stiftung, 1997, 45-51.

LOEST, Erich. Die Stasi war mein Eckermann oder: mein Leben mit der Wanze. Göttingen, Steidl-Verlag, 1991.

MAGENAU, Jörg. Literatur über die Zeitenwende: Wieviel Stoff steckt in der Wende? In: Deutschland (2), Frankfurt a.M., 2009, 56-58.

Nestrovski, Arthur / Seligmann-Silva, Márcio. Apresentação. In: Nestrovski, Arthur / Seligmann-SiLva, Márcio (org.). Catástrofe e representação. São Paulo, Escuta, 2000, 7-12.

Pross, Christian. Vorwort. In: ZILli, Timo. Folterzelle 36 Berlin-Pankow. Erlebnisbericht einer Stasihaft. Berlin, Edition Heinrich, 1993, 7-8.

Seligmann-Silva, Márcio. A história como trauma. In: Nestrovski, Arthur / SELIGMANN-Silva, Márcio (orgs.). Catástrofe e representação. São Paulo, Escuta, 2000, 73-98.

Seligmann-Silva, Márcio. Apresentação da questão. In: Seligmann-Silva, Márcio (org.). História, Memória, Literatura. O testemunho na Era das Catástrofes. Campinas, Ed. Unicamp, 2003, 45-58.

SELigmanN-Silva, Márcio. Literatura de testemunho: os limites entre a construção e a ficção. In: Letras (16), Santa Maria, 1998, 9-37.

Seligmann-Silva, Márcio. O testemunho entre a ficção e o "real”. In: SEligmanNSilva, Márcio (org.). História, Memória, Literatura. O testemunho na Era das Catástrofes. Campinas, Ed. Unicamp, 2003, 375-387. 
Seligmann-Silva, Márcio. Testemunho e a política da memória: o tempo depois das catástrofes. In: Projeto História (30), São Paulo, jun. 2005, 71-98.

SENKMAN, Leonardo. Simja Sneh y los límites de la representación testimonial de la Shoah. In: Seligmann-Silva, Márcio (org.). História, Memória, Literatura. O testemunho na Era das Catástrofes. Campinas, Ed. Unicamp, 2003, 247-297.

WeBER, Sigrid. Relato. In: CAMPHAUSEN, Gabriele. “Zeit-Zeugen“. Inhaftiert in BerlinHohenschönhausen. Berlin, Westkreuz-Druckerei, 1996, 51-52.

ZILLI, Timo. Folterzelle 36 Berlin-Pankow. Erlebnisbericht einer Stasihaft. Berlin, Edition Heinrich, 1993. 